地震第 2 輯

第 44 巻（1991）151-154 頁

\section{やや長周期地震動を用いた 地中埋設地震計の方位推定}

\author{
東京電力株式会社* \\ 植竹富一 \\ 東電設計株式会社** \\ 真下 貢
}

株式会社竹中工務店技術研究所***

天池文男

An Azimuthal Estimation of Underground

Seismographs Using Long Period Ground Motion

Tomiichi Uetake

Tokyo Electric Power Company, Uchisaiwai-cho 1-1-3, Chiyoda-ku, Tokyo 100, Japan

Mitsugu Mashimo

Tokyo Electric Power Services Co., LTD,

Uchisaiwai-cho 1-3-1, Chiyoda-ku,

Tokyo 100, Japan

Fumio Amaike

Technical Research Laboratory, Takenaka

Corporation Minamisuna 2-5-14,

Koto-ku, Tokyo 136, Japan

(Received May 30, 1991;

Accepted July 24, 1991)

\section{§1.はじめに}

近年, 地盤の振動性状や地盤中での地震波動の伝播特 性の把握を目的として, 地盤中でアレ一観測が行われる ようになり, 記録の蓄積, 解析技術の進歩とと屯に精密 な解析が進められつつある。

一方, このアレー記録の解析精度は, 解析手法, 地下 構造のモデル化ばかりでなく, 時刻や地震計設置方位 等, 観测システム自体の精度にも影響されると考えられ る.

このうち埋設地震計の方位については, 設置時に方位 の精度を確保する特別な工夫がなされる場合 [例えば深 掘委員会 (1986)］ああるが, 一般にはボーリング孔頂部 のけがき線や磁石式の方位計で方位を合わせるだけの場

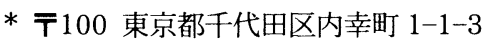

** $\mathbf{T} 100$ 東京都千代田区内幸町 1-3-1 幸ビル 8 階 *** 个136 東京都江東区南砂 2-5-14
合が多いのが現状であろう。埋設地震計の方位について の議論は佐藤・片山 (1983) の例があるものの, 実際に 記録を解析する際には，設置方位が正しいと仮定してい る場合が多いのが実状と考えられる。

今回, 地中地震計の方位推定の試みとして, 東京電力 福島第一原子力発電所構内に設置されている加速度強震 計の方位を, 観測記録に見られた周期数秒〜十数秒の成 分を用いて検討したのでその結果を報告する.

\section{§2. 調査対象地震計の概要}

福島第一原子力発電所は福島県東部にあり, 太平洋に 面して立地している. 今回, 調査対象とした地震計を Fig. 1 に示す. (a) は平面図, (b) は東西方向の断面図で ある. 建屋周辺地盘に設置された地震計のうち, P7 (OP $+13.5 \mathrm{~m}$ : OP は小名浜港の平均海水面を示す) は埋戻 し土上に, P12 (OP-4 m), P4 (OP-18 m), P13 (OP$18 \mathrm{~m}), \mathrm{P} 14(\mathrm{OP}-130 \mathrm{~m})$ は泥岩中に設置されている. また, P3 (OP+1 m), P5 (OP+1 m), P6 (OP+1 m) は建 屋最下部のコンクリートスラブ上に設置されている.

地震計は变位帰還型 (P3, P4: 固有振動数 $f_{0}=450$ $\mathrm{Hz})$ 及び速度㷌還型 (P5 P 14: 固有振動数 $f_{0}=5 \mathrm{~Hz}$ ) の加速度強震計である. 地震観測装置の総合周波数特性
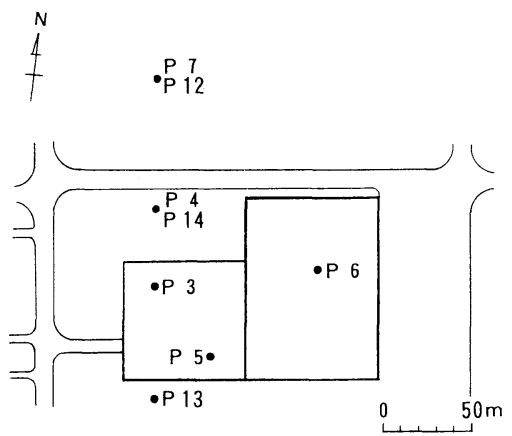

(a) Plan

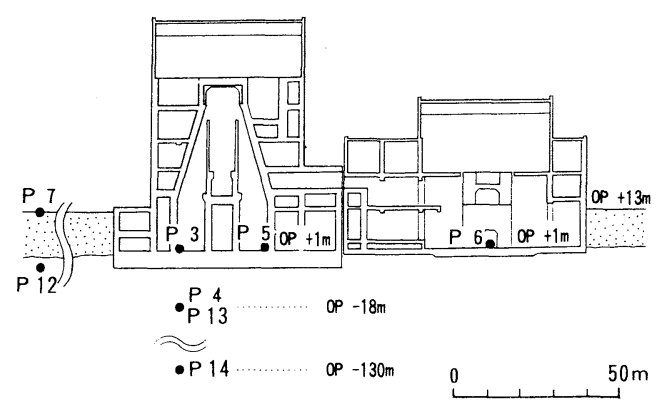

(b) $\mathrm{E}-\mathrm{W}$ section

Fig. 1. Installation points of seismographs in Fukushima-daiichi Nuclear Power Plant. 
は，0.1〜20 Hzでほぼフラットとなっている．収録シス テムは, 最深点 $\mathrm{P} 14$ への入力 $1 \mathrm{gal}$ 以上で起動され, 記 録は，遅延時間 5.12 秒, $\mathrm{AD}$ 変換 $12 \mathrm{bit}$, サンプリング 周波数 $100 \mathrm{~Hz}$ で MT に収録されている.

\section{§3. 方位の推定方法}

地震計が，地表あるいは床面上に設置されていれば, 方位計や周囲の基準となるものを用いて，容易に方位の 確認を行うことができる. しかし，地中に埋設された地 震計については直接地震計を見ることができないため, 従来，重鍾落下や板たたき等の人工震源による地震計の 波形を用いて地震計の方位確認が行われてきた。

これらの人工震源を用いる方法では, 波形が非常に短 周期となるため，地下構造の不整形・不均質の影響を受 けやすいことや，地震計測装置のサンプリング周波数を 十分あげないと解析の精度が落ちてしまう等の問題点が ある.

一方，人工震源の代わりに地震観測記録を用いる方法 がある.この方法では, 各地震計の記録を比較し，その 振動方向のずれから地震計相互の方位のずれを求める.

したがって，新たな実験を行う必要がない代わりに相対 方位しか求まらないという欠点がある，また，短周期成 分の多い記録の場合には，人工震源の場合之同様の問題 が生じることがある.

今回の検討では，地震観測記録を用いる方法を採用す ることとしたが，観測点間の距離に比べ十分波長の長い 波を用いれば，観測点間の不整形・不均質構造に影響さ れることなく精度良く方位を推定できると考え，長周期 成分の $\mathrm{S} / \mathrm{N}$ 比が良い地震記録を用いることとした。た だし，実際の観測記録は，このような長周期成分だけを 含むものではないことから，ここでは観測記録の中から やや長周期成分（周期数秒〜十数秒）を，バンドパス フィルターにより抽出して用いた.

具体的には以下の手順で地震計方位の推定を行った。

(1)記録時間の長い地震記録の中から長周期成分の見ら れる波形を選定する。

(2)記録に，中心周期 $T$ 秒に対して周波数領域で士 $10 \%$ の幅を持つバンドパスフィルターをかける.

(3)その波形から，水平面内のオービットを作成する.

(4)オービットの偏向性がよい部分を選び出す.

(5)地震計ごとに共通時間内でオービットの振動方向の ずれを求め, 地震計の相対方位を推定する.すなわち, 基準となる地震計のオービットに対し，方位を推定する 地震計のオービットが $\theta$ 度ずれていたとすれば，この地 震計は基準となる地震計に対して一 $\theta$ 度ずれて設置され ていることになる。なお，角度は時計回りを正とした。
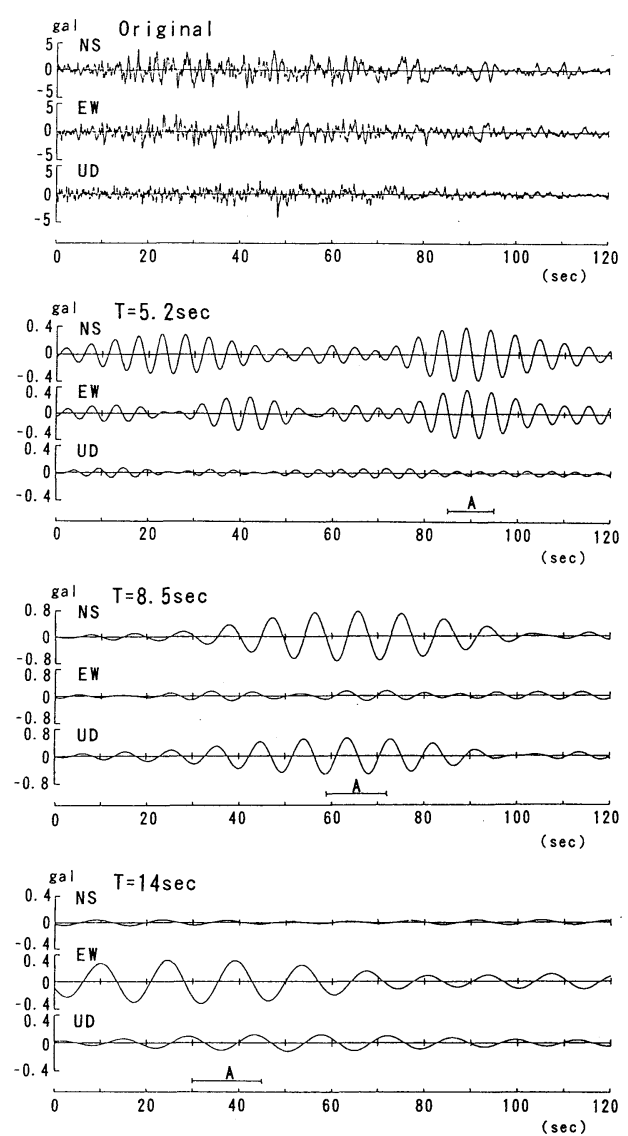

Fig. 2. Original and band-pass filtered seismograms of the 1983 Nihonkai Chubu earthquake at point P3. The center periods of band-pass filter are 5.2, 8.5 and 14 sec. "A" indicate the time interval to draw particle orbits in Fig. 3

また，佐藤・片山 (1983) は，主要動以降のローパス フィルター波形（波形に 0.2 秒及び 1.0 秒の移動平均を 行ったもの）の相関を用いて方位を推定しているが，こ こではバンドパスフィルター波形を用いて同様の検討も 行ってみた。

なお，今回は，基準とする地震計として原子炉建屋最 下部の地震計 $(\mathrm{P} 3)$ を用いた。地震計が設置されている 建屋の振動試験結果によれば，建屋の 1 次固有周期は約 0.3 秒であり, 今回対象とした周期帯では建屋の固有振 動の影響は少ないと考えられる。

\section{§4. 方位の推定結果}

福島第一原子力発電所で得られた記録のうち，長周期 成分が顕著に見られた 1983 年日本海中部地震の記録を 地震計方位の検討に用いた。観測点 P3 での観測波形及 


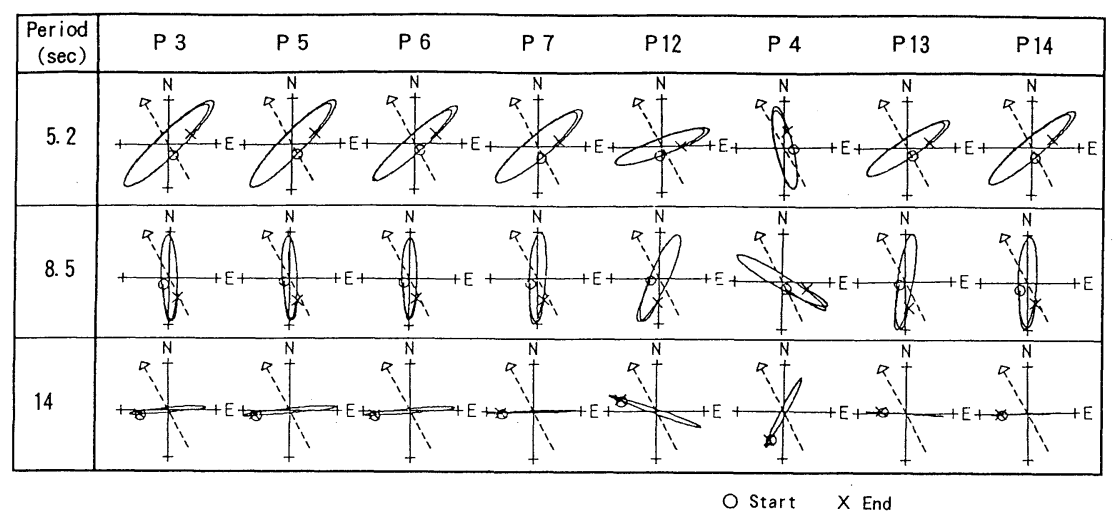

Fig. 3. Filtered seismogram's particle orbits of the 1983 Nihonkai Chubu earthquake. Arrows show the direction of the epicenter.

Table 1. Estimated azimuth of seismographs by long period earthquake ground motion in degree.

\begin{tabular}{|c|c|c|c|c|c|c|}
\hline \multirow{3}{*}{\multicolumn{2}{|c|}{$\begin{array}{l}\text { Installation points } \\
\text { of the seismographs }\end{array}$}} & \multicolumn{4}{|c|}{$\begin{array}{l}\text { Relative azimuth obtained by the difference } \\
\text { of the polarization angle }\end{array}$} & \multirow{4}{*}{$\begin{array}{l}\text { Relative azimuth obtained } \\
\text { by the correlation method } \\
0\end{array}$} \\
\hline & & \multicolumn{3}{|c|}{ Period } & \multirow{3}{*}{$\begin{array}{l}\begin{array}{l}\text { Mean } \\
\text { value }\end{array} \\
0\end{array}$} & \\
\hline & & $5.2 \mathrm{sec}$ & $8.5 \mathrm{sec}$ & $14 \mathrm{sec}$ & & \\
\hline \multirow{3}{*}{$\begin{array}{l}\text { Base of the } \\
\text { building }\end{array}$} & P 3 & 0.0 & 0.0 & 0.0 & & \\
\hline & P 5 & 1.8 & 0.1 & 0.5 & 1 & 0 \\
\hline & P 6 & -2.3 & -1.9 & -0.9 & -2 & -2 \\
\hline \multirow{5}{*}{ Underground } & $P_{7}$ & -4.7 & -5.1 & -4.2 & -5 & -5 \\
\hline & P 12 & -26.3 & -24.1 & -25.0 & -25 & -26 \\
\hline & P 4 & 56.8 & 58.1 & 59.2 & 58 & 57 \\
\hline & $P 13$ & -11.4 & -10.9 & -9.1 & -10 & -11 \\
\hline & P 14 & -4.5 & -5.0 & -4.0 & -5 & -5 \\
\hline
\end{tabular}

Note : Positive direction of azimuth is clockwise.

びそのバンドパスフィルター波形 (中心周期 5.2 秒, 8.5

秒，14 秒）を Fig. 2 に示す.

同記録のバンドパスフィルター波形の振幅が十分大き い部分を選び，水平面内でオービットを描いた．Fig. 2 中 A で示した各区間に対応するオービットを Fig. 3 に 示す．図中の矢印は震央方向を示している，どの観測点 のオービットもほぼ同じ形状の棈円形をしている，建屋 内の P3, P5, P6 及び地盤中の P7, P13, P14 の振動方向 は，ほぼ同一であるが，地盤中の $\mathrm{P} 4, \mathrm{P} 12$ では，振動方 向が他の観測点とかなり異なっている，ただし，地震計 間の相対的ずれ方は周期によらず一定のようである。な お，オービットの振動方向と Fig. 2 の水平動・上下動の 振幅比から, 周期 5.2 秒及び周期 14 秒の波ではラブ波 的な波が卓越し，周期 8.5 秒ではレーリー波的な波が卓 越していると考えられる.

P3 を基準とした各地震計の相対方位を Table 1 に示 す。オービットから求めた各地震計の推定方位は，周期
によらず安定した結果となっており，そのばらつきは大 きくてあ 2 度程度である. 建屋内部の地震計は比較的方 向がそろっており相互のずれは 2 度以内であるが, 地盤 中の地震計の方は相対的にずれが大きく，P4では 58 度，P12では一 25 度という結果となった．また，バンド パスフィルター波形の相関から求めた結果との差異は土 1 度程度であり，両手法での結果はよく一致している.

次に， 3 つの周期の平均として求めた地震計方位の妥 当性を確認するために, 求めた方位を用いて各地震計の 記録を補正し，基準とした建屋内の地震計 P3 の記録と 比較した. Fig. 4 には P3 の記録に地盤中の地震計 P4, P14 の補正前後の記録を重ねて示してある. 補正前に比 べ，補正後はどの周期であ波形の一致度は改善されてお り, 推定した方位の妥当性が示されたといえる. また, 一般に加速度計で長周期を扱う場合，ノイズレベルが問 題となるが，周期 10 秒以上まで波形がよく一致してい ることから，今回用いた記録では長周期まで十分 $\mathrm{S} / \mathrm{N}$ 


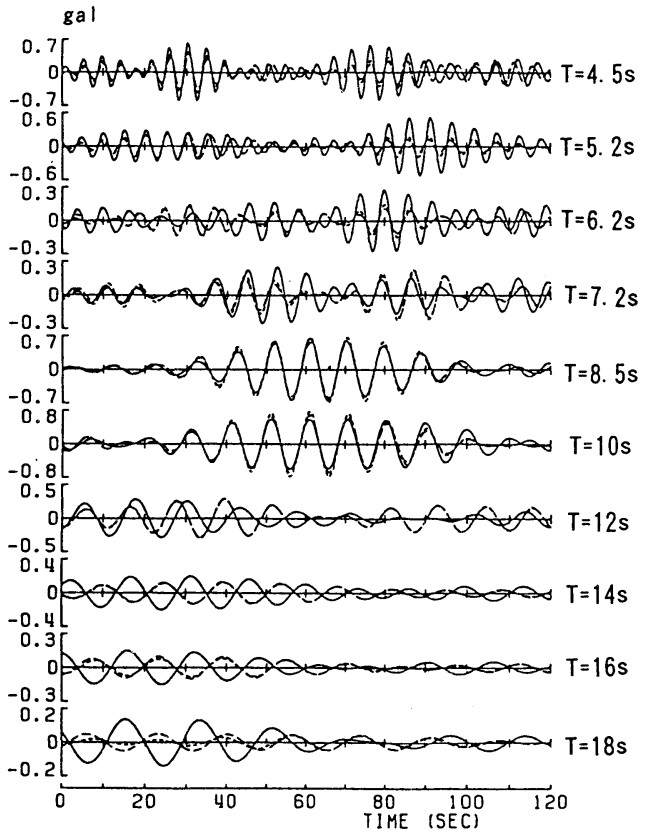

(a) Azimuth not corrected

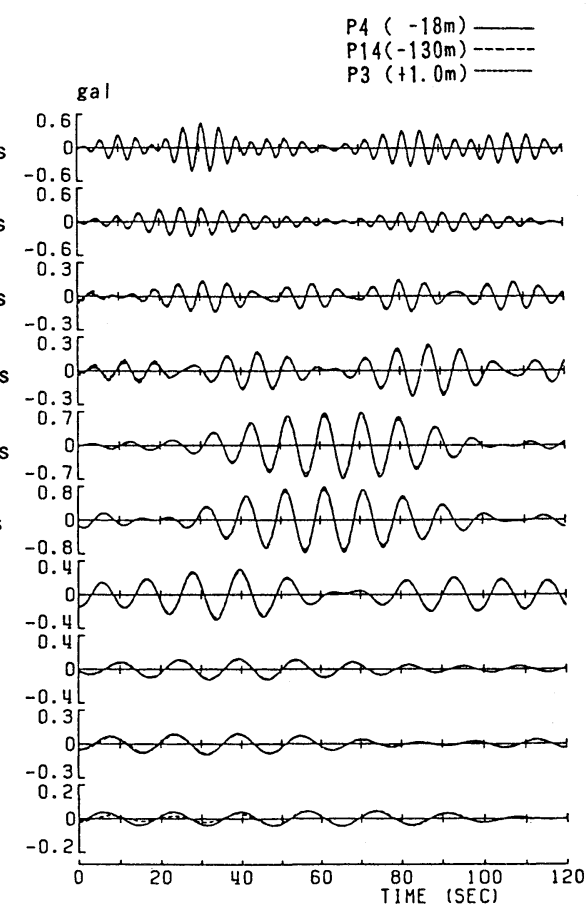

(b) Azimuth corrected

Fig. 4. Band-pass filtered seismograms of radial component of 1983 Nihonkai Chubu earthquake. (a) before and (b) after azimuth correction. In each trace,the center periods of the used band-pass filter are shown.

比がよかったことがわかる.

なお，今回の推定結果では，周期により 1 度前後のば らつきが見られたため，地震計の推定方位としては小数 点以下を四捨五入した値を採用することとした。

\section{§5.おわりに}

今回の調査の結果, 建屋内部の地震計に比べて地盤中 に埋設された地震計でずれが大きいことがわかった。こ の原因として，鉄筋コンクリート製の大きな建屋の存在 により設置時に用いた磁石式方位計の測定精度が低下し た可能性や，地震計を設置用のロッドから切り離して ボーリング孔底部に設置する際に方位のずれが生じた可 能性等が考えられるが，原因を特定することは難しい．

以上のように埋設地震計の方位精度が確保しにくいと いう事実は，地盤中で得られた地震記録を解析する際に は何等かの方法で設置後の地震計方位を確認する必要が あることを示していると考えられる.

また，今回の調查では，地震計の方位推定に地震記録 を比較する方法を用いた。この方法は, 絶対方位を求め る場合には方位の基準となる地震計を必要とするもの
の，磁性体の影響を受けることはなく，また，観測点間 距離に比べて十分長い波長の波を用いることにより，地 盤の不整形・不均質の影響む受けにくいという利点があ る.ただし，この方法の利点を生かすためには，長周期 側で十分 $\mathrm{S} / \mathrm{N}$ 比のよい観測記録が必要である。しかし いずれにしても，現在埋設されている多くの地震計の方 位は誤差を含んでいる可能性が考えられ，記録の利用に あたっては十分な注意が必要といえよう。今回用いた方 位推定法は，その補正の一助となるものと考える.

\section{謝辞}

今回の調査に当たり小林啓美・東京工業大学名誉教授 の多大な御指導を受けました．記して感謝の意を表しま す.

\section{文献}

深掘委員会, 1986, 観測井・実験井の掘削と関連技術, 地質之調查，第 2 号，58-62.

佐藤暢彦・片山恒雄, 1983, 地中地震計の埋設方位の推 定, 第 17 回地震工学研究発表会講演概要, 土木学会, 115-118. 